\section{San Andreas drilling halted}

Berkeley

A PROJECT to drill down to the roots of the San Andreas fault has become one of the first victims of the failure of the National Science Foundation (NSF) to win its expected budget increase.

The Cajon Pass drill-hole, the deepest scientific drill-hole in the United States, was intended to go down to 16,000 feet. But research will stop after the completion of the second of three planned stages, at a depth of 12,000 feet. The project was designed to test a controversial hypothesis that the San Andreas fault is under much less stress than is currently thought.

NSF funds for Deep Observation and Sampling of the Earth's Continental Crust (DOSECC), the non-profit consortium of 40 universities that administers the Cajon Pass project, were cut from an expected $\$ 6$ million to $\$ 3$ million after last autumn's White House/Congress budget summit forced a slowdown in NSF's expansion. The amount available is insufficient to complete this year's drilling or take measurements in the new segment of the hole, says Stanford geophysicist Mark Zoback, director of the Cajon Pass project. But NSF has diverted an additional $\$ 1.8$ million from other projects in its Continental Lithosphere Program, to allow completion of the second phase of drilling and measurements. This reallocation of funds means that the project can expect nothing next year and will remain inactive unless it is refunded in 1990, said DOSECC president, G. Arthur Barber.

Proof that the San Andreas is a lowstress fault depends on sensitive heat-flow measurements which measure friction in the fault. Such measurements become more reliable at greater depths, where they are less likely to be influenced by shallow faults in the area. If the low-stress hypothesis was proved correct, it would mean there must be friction elsewhere resisting the forward motion of the plates, says Zoback, perhaps at horizontal faults deep under the surface.

The importance of the project goes beyond the stress question, according to Barber. Drilling projects are essentially extensions of NSF's individual grant programme because they enable individual researchers to carry out a wide variety of experiments in the hole and on its core. About 40 researchers from 10 universities are involved in the Cajon Pass project.

Barber has now begun to seek corporate funding for DOSECC projects. Petroleum and mineral exploration companies are eager to get involved in the project, he says, because of the technical lessons it is providing in drilling and core handling.

Marcia Barinaga

\title{
Transputer support centres will look for problems to solve
}

\section{London}

This week sees the official opening of the National Transputer Support Centres in Sheffield, part of a government-supported effort to turn microchip manufacturer Inmos into a money-maker instead of an example of British high technology wasted by an inability to apply and profit from an important invention.

Inmos at present is part of the entertainment and electronics group Thorn-EMI, which took the company over in 1985 and has invested heavily in transputer development. But Thorn-EMI is a consumer electronics group and is thought to be anxious to offload Inmos if a willing buyer can be found, despite the fact that Inmos is now at a stage where profits can be expected.$$
\text { expected. }
$$

SERC's own Rutherford Appleton Laboratory; for Northern Ireland both Queens and Ulster Universities are involved; the North West centre is at Liverpool; Scotland at Strathclyde; and the South West at Southampton.

The sixth centre, covering the North East and also taking on a national role in operating a software exchange library, was opened on Monday this week by the Minister for Higher Education and Science, Mr Robert Jackson. The national centre is a joint project of the University of Sheffield and Sheffield City Polytechnic, and the emphasis there will be on engineering.

What will these centres be trying to do? The uniqueness of the transputer lies in its combined programmable processor, ran-

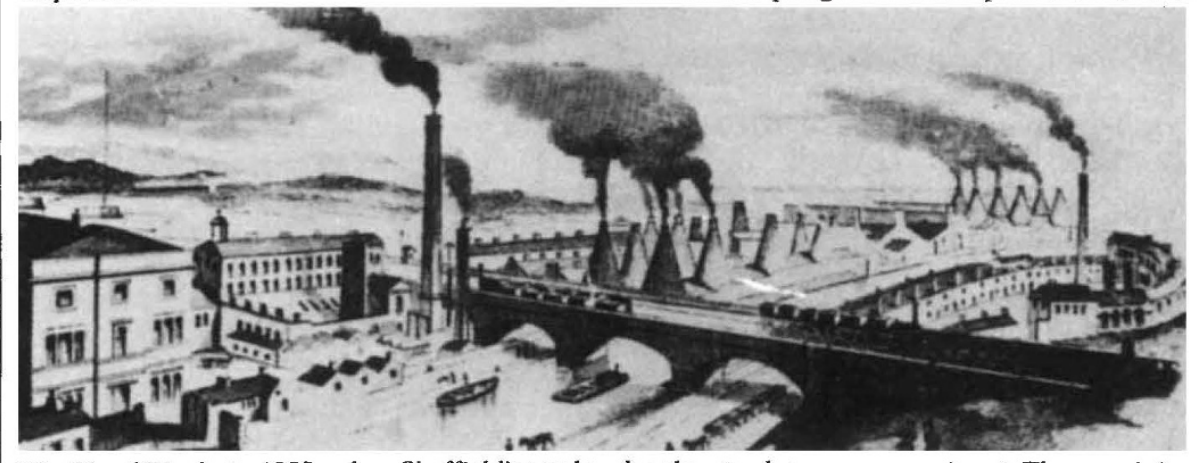

The Sheaf Works in 1855, when Sheffield's steel and cutlery trades were pre-eminent. The remaining building on this site, now a science park, is the first to be occupied by the national centre.

Applications for the transputer are the key to its future, hence the "Transputer Initiative" announced last autumn by the Science and Engineering Research Council (SERC) and the Department of Trade and Industry (DTI). This scheme will spend some $£ 2.6$ million over the next four years on setting up six Regional Support Centres with the brief to provide training and consultancy for industry, to promote research into transputer applications and to develop a software base for the exploitation of the transputer. For London and the South-East the centre will be at dom access memory and communications channels on the one compact chip. The ability of the chips to communicate and process data at the same time makes transputers ideal for potentially powerful 'parallel processing' systems; in addition the transputer makes use of 'Occam', a computer language specifically developed for in-parallel operations.

So the transputer has another four years and $£ 2.6$ million to help it find a market, though Thorn-EMI may consider that too long to wait for a return on its investment. Charles Wenz

\section{Seven new 'specials' for Australia}

\section{Sydney}

Australia is to open seven new "special research centres", bringing the total to fifteen. Called "centres of excellence" when the scheme began in 1982, the new institutions are intended to focus new institutions on research with potential economic benefit. A\$3.6 million will be spent on the centres this year. Among the recipients are Jack Pettigrew, who will head Queensland's first centre, for vision, touch and hearing. Pettigrew has been successful in exploiting basic research on animals to develop a new binaural hearing aid.

Other centres are for human communication (Graeme Clark, Melbourne), protein and enzyme technology (Richard Wetterall and Robert Scopes, La Trobe), electronic structure of materials (Ian McCarthy and Erich Weigold, Flinders), lasers (James Piper, Macquarie), membrane and separation technology (Christopher Fell and Hans Coster, New South Wales), and industrial control science (Graham Goodwin, Newcastle).

Charles Morgan 